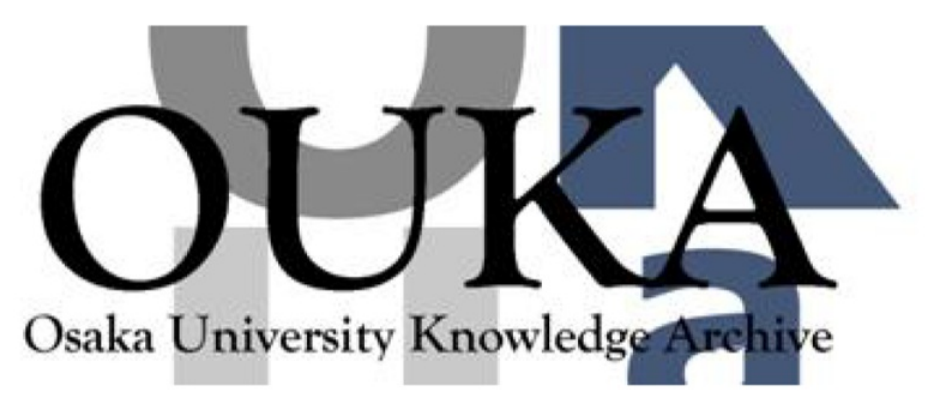

\begin{tabular}{|c|l|}
\hline Title & $\begin{array}{l}\text { Enhancement of Au Dissolution by Microorganisms } \\
\text { Using an Accelerating Cathode Reaction }\end{array}$ \\
\hline Author(s) & $\begin{array}{l}\text { Kita, Yoshito; Nishikawa, Hiroshi; Ike, } \\
\text { Michihiko et al. }\end{array}$ \\
\hline Citation & $\begin{array}{l}\text { Metallurgical and Materials Transactions B. } \\
40(1) \text { p. 39-p. } 44\end{array}$ \\
\hline Issue Date & $2009-02$ \\
\hline oaire:version VoR \\
\hline URL & https://hdl. handle.net/11094/2893 \\
\hline rights & \\
\hline Note & \\
\hline
\end{tabular}

Osaka University Knowledge Archive : OUKA

https://ir. Library. osaka-u. ac. jp/

Osaka University 


\title{
Enhancement of Au Dissolution by Microorganisms Using an Accelerating Cathode Reaction
}

\author{
YOSHITO KITA, HIROSHI NISHIKAWA, MICHIHIKO IKE, \\ and TADASHI TAKEMOTO
}

\begin{abstract}
A Chromobacterium violaceum $(C$. violaceum) strain that produces cyanide was used to dissolve $\mathrm{Au}$. In this bacterial $\mathrm{Au}$ dissolution process, decreased dissolved oxygen concentration in the bacterial medium significantly inhibits Au dissolution. Although aeration is effective in increasing the level of dissolved oxygen in the bacterial medium, it is not effective in increasing Au dissolution during the growth phase of the bacteria because of the latter's high respiratory consumption of oxygen. The present study investigated the utility of $\mathrm{H}_{2} \mathrm{O}_{2}$, rather than aeration, for increasing dissolved oxygen concentrations in bacterial growth medium. It was anticipated that the stronger oxidation reagent would increase $\mathrm{Au}$ dissolution by accelerating the cathode reaction during the bacterial growth phase. In fact, the addition of $\mathrm{H}_{2} \mathrm{O}_{2}$ to the bacterial culture increased dissolved oxygen concentrations in the growth phase and also drastically increased the dissolution rate of $\mathrm{Au}$. Electrochemical measurements indicated that $\mathrm{H}_{2} \mathrm{O}_{2}$ addition to the bacterial medium accelerated the cathode reaction and thus enhanced Au dissolution by this biological process.
\end{abstract}

DOI: $10.1007 / \mathrm{s} 11663-008-9177-\mathrm{z}$

(C) The Minerals, Metals \& Materials Society and ASM International 2008

\section{INTRODUCTION}

IN electronic assembly processes, $\mathrm{Au}$ is frequently used for surface plating and bonding wires due to its excellent bonding characteristics. At the same time, the amount of $\mathrm{Au}$ used in recent high density surface mount boards decreases due to advanced thin plating and joining technologies. Gold is a precious metal and is highly valued for its physicochemical properties; thus, it is desirable to recover $\mathrm{Au}$ from industrial waste. ${ }^{[1]} \mathrm{At}$ present, metallic scraps containing $\mathrm{Au}$ are generally treated by hydrometallurgical methods such as aqua regia or cyanidation. While excessive use of cyanide for the dissolution of $\mathrm{Au}$ is associated with environmental risk, biological $\mathrm{Au}$ dissolution methods produce little cyanide and, when coupled with subsequent detoxification, ${ }^{[2,3]}$ are particularly environmentally friendly processes.

Chromobacterium violaceum (C. violaceum) is a mesophilic, motile, Gram-negative, facultative anaerobe. ${ }^{[4]}$ Strains of this microorganism produce cyanide ${ }^{[5]}$ and can subsequently detoxify the cyanide using $\beta$-cyanoalanine synthase when grown in minimal medium. ${ }^{[6-8]}$ Therefore, this strain can potentially be used in ecologically-friendly $\mathrm{Au}$ recovery processes. ${ }^{[9,10]}$

YOSHITO KITA, Graduate Student, is with Graduate School of Engineering, Osaka University, Ibaraki, Osaka 567-0047, Japan. Contact e-mail: kitayokitayo@gmail.com HIROSHI NISHIKAWA, Associate Professor, and TADASHI TAKEMOTO, Professor, are with Joining and Welding Research Institute, Osaka University, Ibaraki, Osaka 567-0047, Japan. MICHIHIKO IKE, Professor, is with Department of Environmental Engineering, Osaka University, Suita, Osaka 565-0871, Japan.

Manuscript submitted November 5, 2007.

Article published online December 10, 2008.
The Au dissolution in cyanide solution consists of an anode Reaction [1] and a cathode Reaction [2]. These reactions are summarized by Elsner's Eq. [3]:[11]

$$
\begin{gathered}
4 \mathrm{Au}+8 \mathrm{CN}^{-} \rightarrow 4 \mathrm{Au}(\mathrm{CN})_{2}^{-}+4 \mathrm{e}^{-} \\
\mathrm{O}_{2}+2 \mathrm{H}_{2} \mathrm{O}+4 \mathrm{e}^{-} \rightarrow 4 \mathrm{OH}^{-} \\
4 \mathrm{Au}+8 \mathrm{CN}^{-}+\mathrm{O}_{2}+2 \mathrm{H}_{2} \mathrm{O} \rightarrow 4 \mathrm{Au}(\mathrm{CN})_{2}^{-}+4 \mathrm{OH}^{-}
\end{gathered}
$$

The rate of Au dissolution depends on a number of factors, including cyanide concentration, Au surface area, ${ }^{[12,13]}$ mixing, solution conditions (temperature and $\mathrm{pH}$ ), interference from other materials, and dissolved oxygen concentration. ${ }^{[14,15]}$ Electrochemically, cyanide and oxygen concentrations are important factors affecting the dissolution of $\mathrm{Au},{ }^{[16-18]}$ and aeration of the bacterial suspension effectively increases the $\mathrm{Au}$ dissolution rate. ${ }^{[10]}$ However, during the growth phase, when C. violaceum rapidly consumes dissolved oxygen for bacterial respiration, Au dissolution is inhibited due to suppression of the cathode reaction arising from insufficient dissolved oxygen.

The aim of this study was to investigate the effect of $\mathrm{H}_{2} \mathrm{O}_{2}$ as an efficient source of oxygen on the $\mathrm{Au}$ dissolution rate during the growth phase of $C$. violaceum.

\section{MATERIALS AND METHODS}

\section{A. Organism and Culture Conditions}

Chromobacterium violaceum NBRC 12614 was grown in flasks containing YP medium (polypeptone $10 \mathrm{~g}$, 
yeast extract $2 \mathrm{~g}, \mathrm{MgSO}_{4} 7 \mathrm{H}_{2} \mathrm{O} 1 \mathrm{~g}$, and distilled water $1 \mathrm{~L})$ at $30{ }^{\circ} \mathrm{C}$ with agitation at $110 \mathrm{rpm}$.

\section{B. Au Dissolution from Powder}

For the $\mathrm{Au}$ dissolution test, $0.5 \mathrm{~mol} \mathrm{Au}$ powder (superficial area, $0.4 \mathrm{~m}^{2} / \mathrm{g}$; average particle diameter, $1.1 \mu \mathrm{m}$; and tap density, $6.4 \mathrm{~g} / \mathrm{cm}^{3}$ ) was added to a $500-\mathrm{mL}$ conical flask containing $300 \mathrm{~mL}$ YP medium inoculated with $3.0 \mathrm{~mL}$ actively growing $C$. violaceum culture. To accelerate cyanide production by $C$. violaceum, $30 \mathrm{mmol} / \mathrm{L}$ glycine was added to the medium. ${ }^{[9]} \mathrm{In}$ order to increase the dissolved oxygen concentration, either $1.0 \mathrm{~mL} \mathrm{H}_{2} \mathrm{O}_{2}$ solution was added to the culture every 5 minutes or aseptic air was blown into the flask at $100 \mathrm{~mL} / \mathrm{min}$. During the dissolution test, the culture was incubated at $30^{\circ} \mathrm{C}$ and mixed at $110 \mathrm{rpm}$.

\section{Electrochemical Measurements}

In order to investigate the electrochemical behavior of $\mathrm{Au}$, the rest potential of $\mathrm{Au}$ in the culture medium was measured using a potentiostat and a function generator. The $\mathrm{Au}$ plate (purity $99.99 \mathrm{pct}$ ), $\mathrm{Pt}$ wire, and $\mathrm{Ag} / \mathrm{AgCl}$ were used as a working electrode, a counter electrode, and a standard electrode, respectively. The Au plate and $\mathrm{Pt}$ wire surfaces were polished using emery paper and finished with $1-\mu \mathrm{m}$ diamond powder. The working electrodes were encapsulated in epoxy resin except for a $1.0 \mathrm{~cm}^{2}$ surface area at one side. The solution was stirred and maintained at $30{ }^{\circ} \mathrm{C}$. Figure 1 presents a schematic diagram of the electrochemical experiment.

\section{Analysis}

Bacterial growth was monitored by plate counts on YP agar medium (YP medium with agar, $15 \mathrm{~g}$ ). Viable suspended cells were counted using the drop plate method with serial dilution on YP medium. Plates were incubated for 24 hours at $37^{\circ} \mathrm{C}$.

Total cyanide concentration was analyzed colorimetrically at $520 \mathrm{~nm}$ using the picric acid colorimetric method. The Au concentration was analyzed by atomic absorption analysis. The dissolved oxygen concentration was measured with a dissolved oxygen sensor connected to a handheld dissolved oxygen meter.

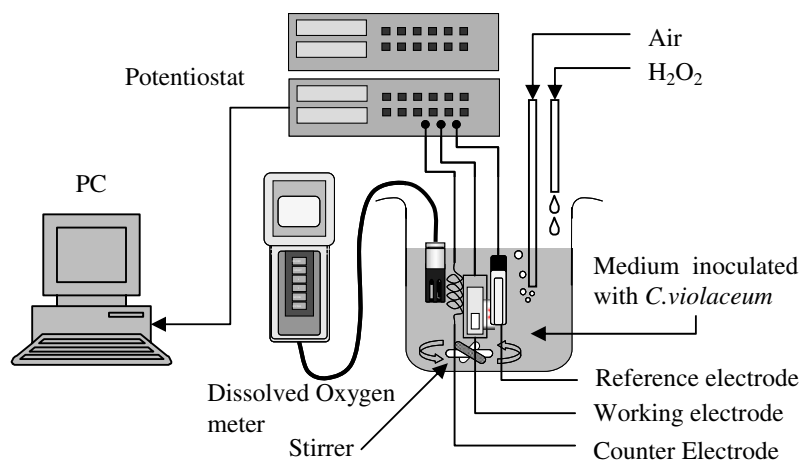

Fig. 1-Schematic diagram of the electrochemical experiment.

\section{RESULTS AND DISCUSSION}

\section{A. Effects of $\mathrm{H}_{2} \mathrm{O}_{2}$ Addition on Dissolved Oxygen Concentration during the Growth of $C$. violaceum}

Figure 2(a) shows the change in the $C$. violaceum cell population, while Figure 2(b) shows the cyanide and dissolved oxygen concentrations during the growth of the bacteria for up to 120 hours. The $C$. violaceum cell population rapidly increased from $2.0 \times 10^{7}$ to $2.0 \times$ $10^{9}$ cells $/ \mathrm{mL}$ during the first 24 hours, after which the population stabilized, while the cyanide concentration rapidly increased from 0 to $0.55 \mathrm{mmol} / \mathrm{L}$ in the first 24 hours, peaked $(0.7 \mathrm{mmol} / \mathrm{L})$ at 48 hours, and then decreased. Two phases are evident from these results: C. violaceum rapidly produces cyanide in the growth phase and gradually decreases cyanide production in stationary phase.

In contrast, dissolved oxygen concentration rapidly decreased in the growth phase ( 0 to 48 hours) and remained low $(0.05 \mathrm{mmol} / \mathrm{L})$ in the stationary phase. Based on the dissolved oxygen concentration, it is clear that $C$. violaceum consumes dissolved oxygen for bacterial respiration during the growth and stationary

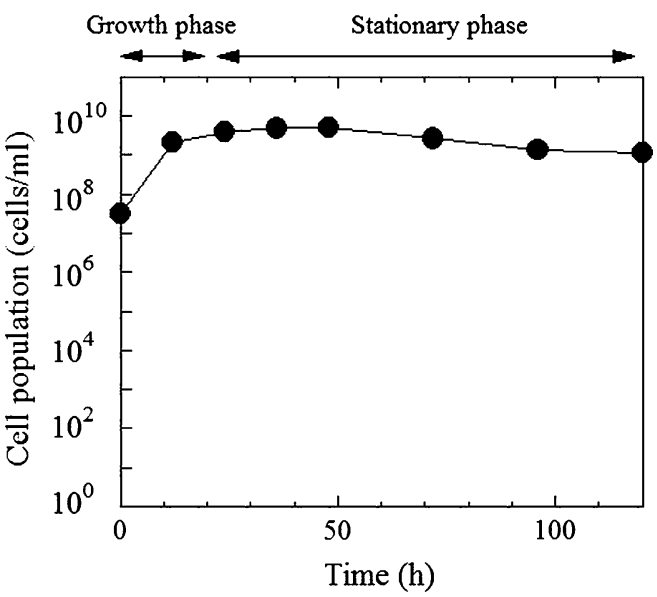

(a)

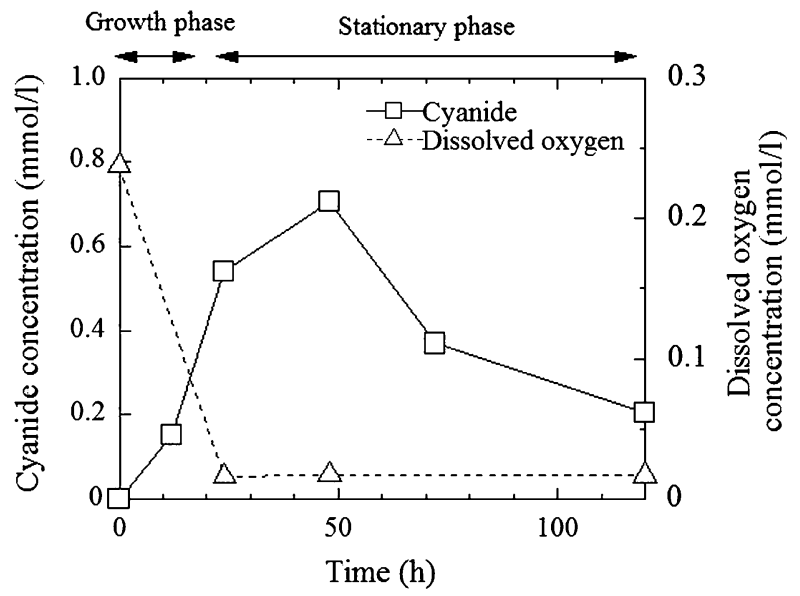

(b)

Fig. 2-Cyanide production by $C$. violaceum: $(a)$ cell population of C. violaceum $(\bullet)$ in the culture; and $(b)$ cyanide concentration $(\square)$ and dissolved oxygen concentration $(\Delta)$ in the culture medium. 
phases. ${ }^{[19]}$ This decrease inhibits the cathode reaction and may decrease the $\mathrm{Au}$ dissolution rate. Aeration increases both dissolved oxygen concentration and the $\mathrm{Au}$ dissolution rate during the stationary phase ${ }^{[10]}$ but does not increase dissolved oxygen concentration during the growth phase when $C$. violaceum rapidly consumes dissolved oxygen. The Au dissolution might be increased by increasing dissolved oxygen during the growth phase, when $C$. violaceum can produce significant cyanide.

$\mathrm{H}_{2} \mathrm{O}_{2}$ is an efficient oxygen source. ${ }^{[20]}$ Figure 3 shows the change in dissolved oxygen concentration of a C. violaceum culture incubated for 24 hours (from Figure 2) after $\mathrm{H}_{2} \mathrm{O}_{2}$ addition. Dissolved oxygen concentration increased after $\mathrm{H}_{2} \mathrm{O}_{2}$ addition, peaking after about 0.05 hours; it then decreased from 0.15 to 0.20 hours after addition. Figure 4 depicts the maximum dissolved oxygen concentration derived from Figure 3. As $\mathrm{H}_{2} \mathrm{O}_{2}$ concentration increased from 0 to 0.0018 pct, dissolved oxygen concentration increased almost linearly, while the oxygen content remained almost constant at higher $\mathrm{H}_{2} \mathrm{O}_{2}$ concentration. The bacterial culture frothed when more than 0.01 pet $\mathrm{H}_{2} \mathrm{O}_{2}$ was added.

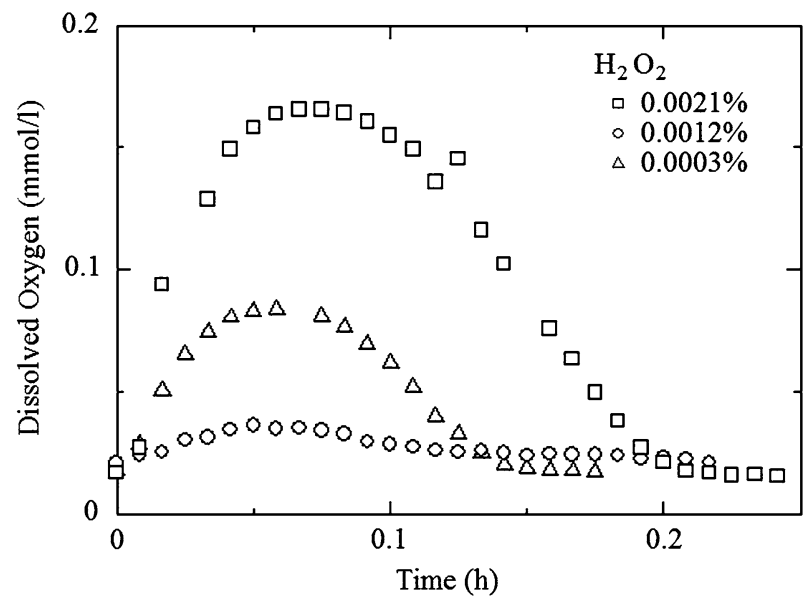

Fig. 3 - Changes in dissolved oxygen concentration in C. violaceum cultures following incubation for $24 \mathrm{~h}$ (from Fig. 2), after the addition of $\mathrm{H}_{2} \mathrm{O}_{2}: 0.0003$ pct $(O), 0.0012$ pct $(\triangle)$, and 0.0021 pet $(\square)$.

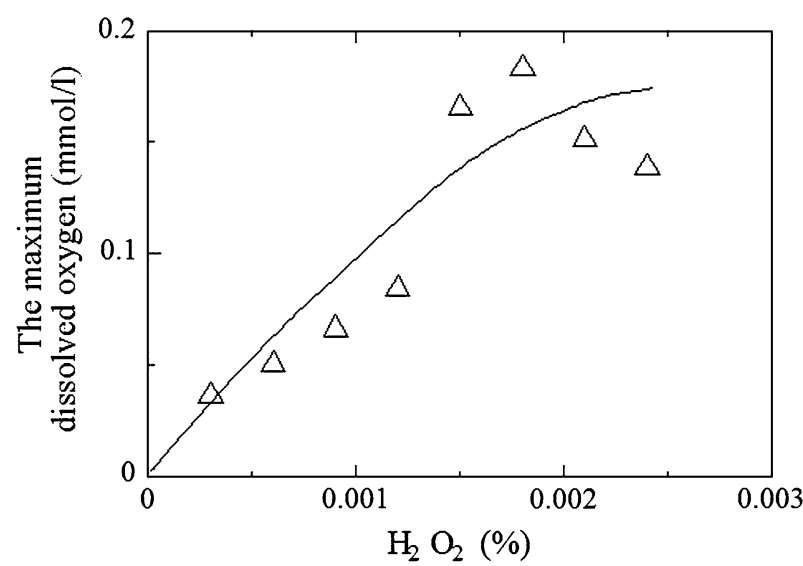

Fig. 4-Maximum dissolved oxygen concentration of the cultures, as calculated from Fig. 3.
The addition of $\mathrm{H}_{2} \mathrm{O}_{2}$ increased dissolved oxygen concentration even during the growth phase, although the dissolved oxygen level seemed to saturate at $0.23 \mathrm{mmol} / \mathrm{L}\left(30^{\circ} \mathrm{C}\right)$. The addition of $\mathrm{H}_{2} \mathrm{O}_{2}$ can increase dissolved oxygen levels for about 0.15 hours (Figure 3); accordingly, the addition of $\mathrm{H}_{2} \mathrm{O}_{2}$ every 0.08 hour maintained higher dissolved oxygen concentration.

\section{B. $\mathrm{H}_{2} \mathrm{O}_{2}$ Tolerance of $\mathrm{C}$. violaceum}

$\mathrm{H}_{2} \mathrm{O}_{2}$ is an excellent oxygen source and also acts as an antimicrobial agent. ${ }^{[21]}$ The $\mathrm{H}_{2} \mathrm{O}_{2}$ tolerance of $C$. violaceum was investigated by determining the number of bacteria following $\mathrm{H}_{2} \mathrm{O}_{2}$ addition to the culture. Figure 5 shows the $C$. violaceum cell population in the 24-hour cultures (from Figure 2) after adding $\mathrm{H}_{2} \mathrm{O}_{2}$ and incubating for 10 minutes. The cell populations were maintained above $10^{9}$ cells $/ \mathrm{mL}$, indicating that $C$. violaceum tolerates $\mathrm{H}_{2} \mathrm{O}_{2}$ below 0.01 pet $\mathrm{H}_{2} \mathrm{O}_{2}$, while more than 0.1 pct $\mathrm{H}_{2} \mathrm{O}_{2}$ is clearly toxic. In this experiment, $\mathrm{H}_{2} \mathrm{O}_{2}$ tolerance was based on a previous report. ${ }^{[10]}$

$\mathrm{H}_{2} \mathrm{O}_{2}$ at a concentration of 0.0021 pct can increase dissolved oxygen concentration, as shown in Figure 4, without damaging the $C$. violaceum population, because the bacteria can tolerate $\mathrm{H}_{2} \mathrm{O}_{2}$ up to 0.1 pct. The addition of $\mathrm{H}_{2} \mathrm{O}_{2}$ appears to be a useful oxygen source for increasing bacterial $\mathrm{Au}$ dissolution rates by increasing the dissolved oxygen concentration (cathode reaction) in bacterial cultures.

\section{Effects of $\mathrm{H}_{2} \mathrm{O}_{2}$ on Bacterial Au Dissolution}

Figure 6 shows the cyanide concentration (Figure 6 (a)), dissolved oxygen concentration (Figure 6(b)), and $\mathrm{Au}$ concentration (Figure 6(c)) in C. violaceum cultures with added $\mathrm{H}_{2} \mathrm{O}_{2}$, with and without aeration. The cyanide concentration increased almost linearly over 27 hours, reaching a concentration of $2.3 \mathrm{mmol} / \mathrm{L}$. The addition of $\mathrm{H}_{2} \mathrm{O}_{2}$ increased the dissolved oxygen concentration above $0.1 \mathrm{mmol} / \mathrm{L}$ throughout the experiment, while aeration increased dissolved oxygen concentration to $0.1 \mathrm{mmol} / \mathrm{L}$ only after 27 hours. Without the addition of

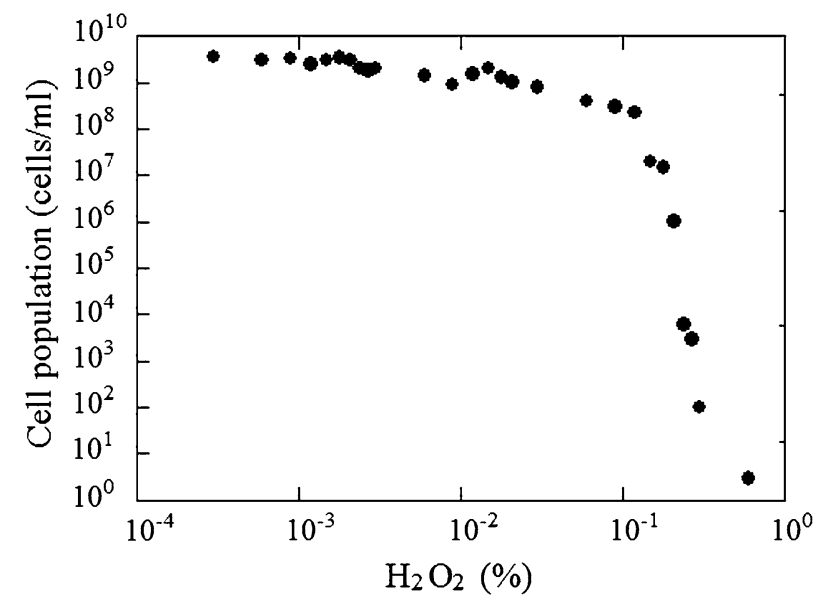

Fig. 5-C. violaceum cell population in 24-h cultures (Fig. 2) after the addition of $\mathrm{H}_{2} \mathrm{O}_{2}$ and incubation for $10 \mathrm{~min}$. 


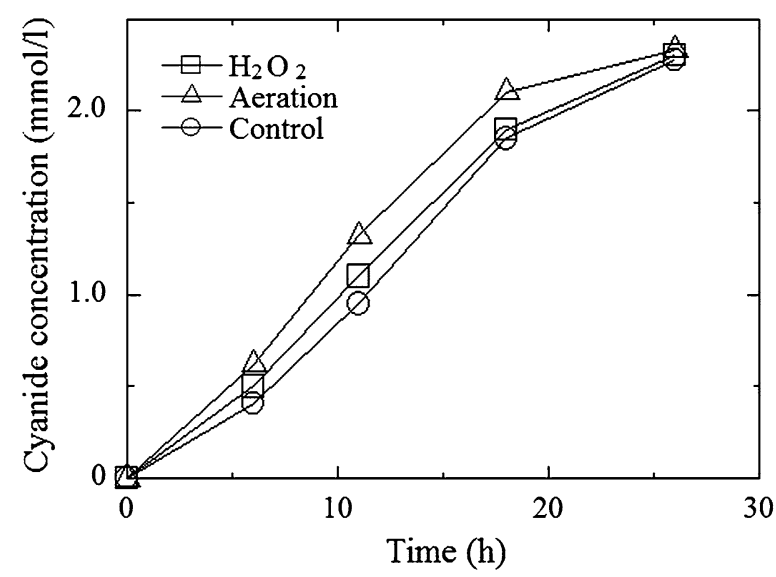

(a)

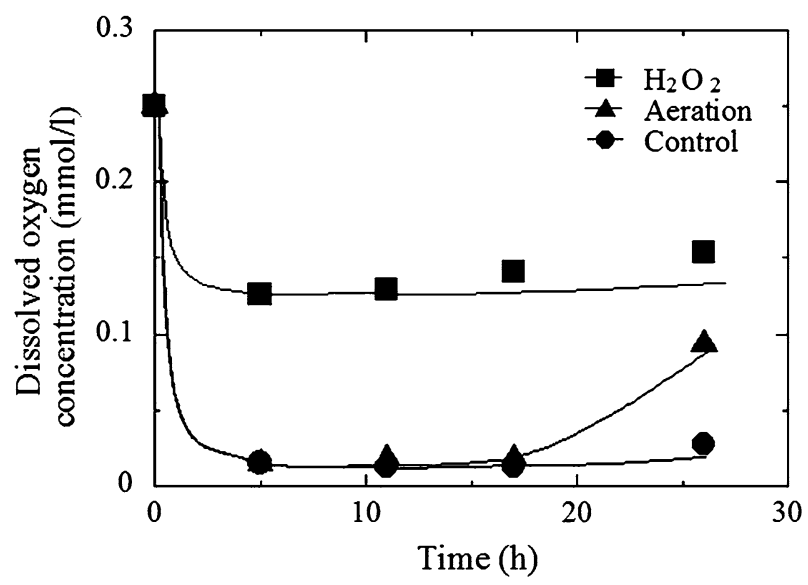

(b)

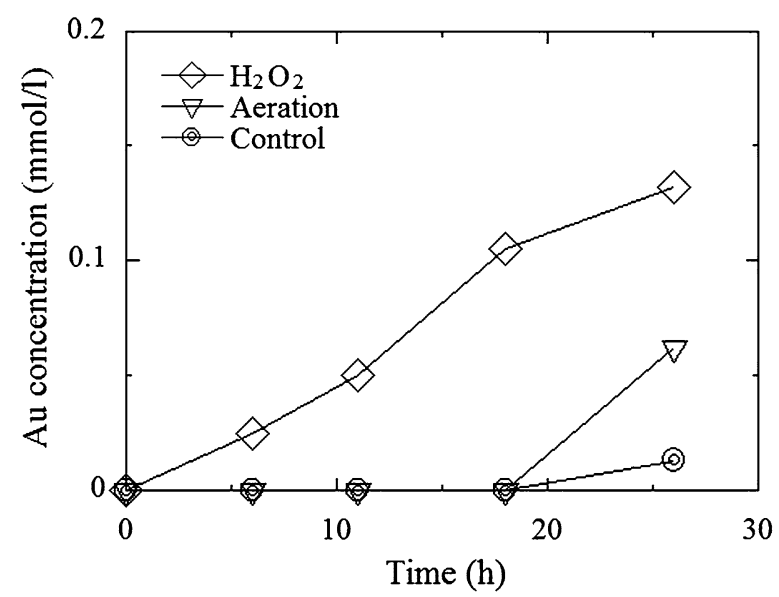

(c)

Fig. 6 - Gold dissolution in cultures with added Au powder and portionwise addition of hydrogen peroxide, with and without aeration. (a) Cyanide concentration in the culture medium with $\mathrm{H}_{2} \mathrm{O}_{2}(\square)$, with $(\triangle)$ and without $(O)$ aeration. (b) Dissolved oxygen concentration in the culture medium with $\mathrm{H}_{2} \mathrm{O}_{2}(\boldsymbol{\square})$, with $(\boldsymbol{\Delta})$ and without $(\bullet)$ aeration. $(c)$ Au concentration in the culture medium with $\mathrm{H}_{2} \mathrm{O}_{2}$ $(\diamond)$, with $(\nabla)$ and without $(@)$ aeration.

$\mathrm{H}_{2} \mathrm{O}_{2}$ or aeration, dissolved oxygen concentration was consistently less than $0.04 \mathrm{mmol} / \mathrm{L}$. The addition of $\mathrm{H}_{2} \mathrm{O}_{2}$ accelerated $\mathrm{Au}$ dissolution, resulting in $0.13 \mathrm{mmol} / \mathrm{L}$ dissolved Au after 27 hours, while concentrations of only

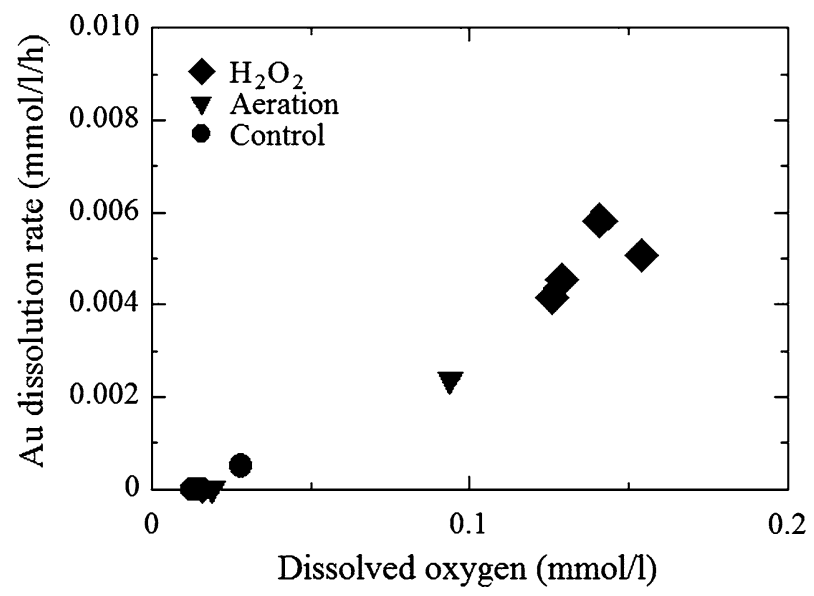

Fig. 7-Effects of dissolved oxygen concentration on the Au dissolution rate (Fig. 5(c)).

0.06 and $0.02 \mathrm{mmol} / \mathrm{L}$ dissolved $\mathrm{Au}$ were achieved with and without aeration after 27 hours, respectively.

Figure 7 plots the $\mathrm{Au}$ dissolution rate (taken from Figure 6(c)) and dissolved oxygen concentration (taken from Figure 6(b)) in bacterial cultures without aeration, with aeration, and upon addition of $\mathrm{H}_{2} \mathrm{O}_{2}$. As the plots show a linear relationship, it is clear that increased dissolved oxygen enhances the $\mathrm{Au}$ dissolution rate. As indicated in Figure 6, the highest dissolution rate was obtained in $\mathrm{H}_{2} \mathrm{O}_{2}$-treated cultures with maximum dissolved oxygen. $\mathrm{H}_{2} \mathrm{O}_{2}$ addition was effective in enhancing $\mathrm{Au}$ dissolution by accelerating the cathode reaction by increasing the dissolved oxygen level in bacterial cultures. Accordingly, the low Au dissolution rate observed during the growth phase is due to the process being severely suppressed by the lack of dissolved oxygen.

\section{Electrochemical Measurement}

Figure 8(a) shows the changes in the resting potential of $\mathrm{Au}$ plate in $\mathrm{H}_{2} \mathrm{O}_{2}$-added $C$. violaceum cultures incubated for 24 hours. Figure 8(b) plots the resting potential of $\mathrm{Au}$ plate (from Figure 8(a)) as a function of the dissolved oxygen concentration in $\mathrm{H}_{2} \mathrm{O}_{2}$-added C. violaceum cultures (shown in Figure 3). All data lie on a straight line irrespective of $\mathrm{H}_{2} \mathrm{O}_{2}$ concentration. This type of change in resting potential is called Nernstiantype change ${ }^{[22,23]}$ and indicates that the reaction is controlled by only the cathode reaction. In fact, the cyanide concentration of the culture was constant before and after $\mathrm{H}_{2} \mathrm{O}_{2}$ addition.

Figure 9 details the changes in the resting potential and the current density of Au plate in the C. violaceum culture. The $\mathrm{Au}$ dissolution increases with increasing charge current density. To enhance Au dissolution, both the anode and cathode reactions must be accelerated by increasing cyanide (line shift from e to d) and dissolved oxygen (line shift from a to c) concentrations. During the growth phase, the anode reaction is accelerated (line $\mathrm{d}$ ) but the cathode reaction is inhibited (line a) due to consumption of oxygen by bacterial respiration, while C. violaceum can produce high concentrations of cyanide 


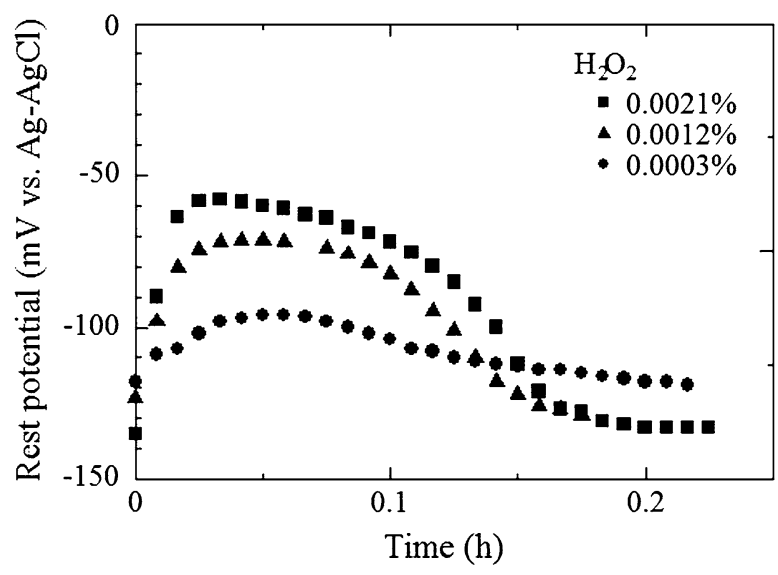

(a)

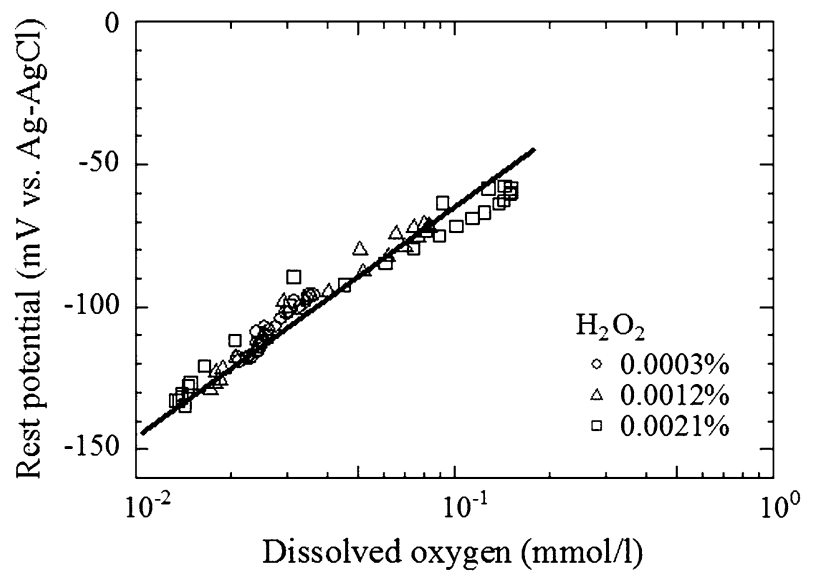

(b)

Fig. 8- (a) Rest potential of Au plate in the culture medium in which $C$. violaceum was incubated for $24 \mathrm{~h}$ (Fig. 3(a)) after addition of 0.0003 pct $(\bullet), 0.0012$ pct $(\mathbf{\Delta})$, and 0.0021 pct ( $\square$ ) hydrogen peroxide. $(b)$ Effects of dissolved oxygen concentration on resting potential (Fig. 7(a)).

despite the low concentration of dissolved oxygen. Accordingly, the electrochemical reaction during the growth phase can be expressed by the point M. In contrast, during the stationary phase, cyanide concentration decreases (line e) and dissolved oxygen concentration remains constant (line a), while $C$. violaceum decomposes cyanide and consumes dissolved oxygen by bacterial respiration. Aeration did not increase dissolved oxygen concentration during the growth phase due to rapid consumption by bacterial respiration. The reaction of the stationary phase was maintained at point $\mathrm{M}^{\prime}$, but the increased dissolved oxygen concentration shifts the variation point from $\mathrm{M}^{\prime}$ to $\mathrm{P}$. Accordingly, the $\mathrm{Au}$ dissolution rate increased during the stationary phase compared with that of the growth phase, as shown in Figure 6(c). The addition of $\mathrm{H}_{2} \mathrm{O}_{2}$ increased dissolved oxygen concentration even during the growth phase, resulting in increased $\mathrm{Au}$ dissolution rate, as shown in Figures 6(b) and (c). The increase in the resting potential of $\mathrm{Au}$ plate in the bacterial culture by the addition of $\mathrm{H}_{2} \mathrm{O}_{2}$ in Figure 8(b) represents the increase in the resting potential from point $\mathrm{M}$ to $\mathrm{N}$ in Figure 9. Therefore, the present study clarified that $\mathrm{H}_{2} \mathrm{O}_{2}$ is an effective oxygen

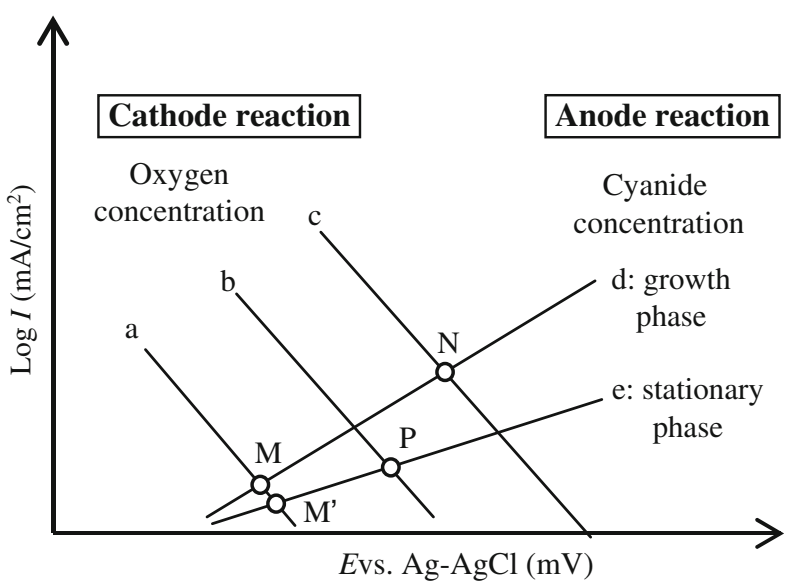

Fig. 9-Change in the resting potential of $\mathrm{Au}$ on biological gold leaching. Lines a, b, and c indicate the cathode curves for the control, upon aeration, and upon addition of $\mathrm{H}_{2} \mathrm{O}_{2}$ to the bacterial cultures, respectively. Lines $\mathrm{d}$ and e indicate the anodic curves for the growth and stationary phases, respectively.

source and that bacterial dissolution of $\mathrm{Au}$ during the growth phase is controlled by the cathode reaction.

\section{CONCLUSIONS}

Chromobacterium violaceum produces cyanide and was used to dissolve $\mathrm{Au}$. To increase $\mathrm{Au}$ dissolution during the growth phase, when $C$. violaceum rapidly consumes dissolved oxygen by respiration, the effects of aeration and addition of $\mathrm{H}_{2} \mathrm{O}_{2}$ to the bacterial culture on the $\mathrm{Au}$ dissolution rate were examined. The resting potential in the bacterial culture was measured to investigate the cathode reaction and the effect of increasing dissolved oxygen concentration on $\mathrm{Au}$ dissolution. Based on the results presented in this article, the following conclusions can be drawn.

1. During the growth phase, $C$. violaceum produces a higher concentration of cyanide and rapidly consumes dissolved oxygen by bacterial respiration.

2. Addition of $\mathrm{H}_{2} \mathrm{O}_{2}$ to the bacterial culture increases dissolved oxygen concentration even during the growth phase and increases the $\mathrm{Au}$ dissolution rate, while aeration does not increase the dissolved oxygen concentration during the growth phase due to rapid bacterial respiration.

3. C. violaceum tolerates $\mathrm{H}_{2} \mathrm{O}_{2}$ up to $0.01 \mathrm{pct}$, and this concentration is effective in increasing the Au dissolution rate during the growth phase.

4. The electrochemical study clarified that the Au dissolution reaction in bacterial cultures is controlled by the cathode reaction due to severe oxygen shortage arising from bacterial respiration during the growth phase.

\section{REFERENCES}

1. T. Fujita and W.T. Yen: Symp. on Actions for Environmental Concern in Electronics Assembly, Tokyo and Osaka (2 days), Japan, 2001, pp. 118-27. Available at: http://wwwsoc.nii.ac.jp/jws/ research $/ \mathrm{micro} /$ aecea/aecea $\% 207 . \mathrm{html}$ (the site is Japanese only). 
2. D. Norman and R. Raforth: Wash. Geol., 1995, vol. 23 (1), pp. $30-41$.

3. G. Olson: FEMS Microbiol. Lett., 1994, vol. 119, pp. 1-6.

4. M. Moss and C. Ryall: The Prokaryotes, 2nd ed., Springer-Verlag, New York, NY, 1981, pp. 1356-64.

5. R. Michaels and W. Corpe: J. Bacteriol., 1965, vol. 89 (1), pp. $106-12$.

6. A.M. Macadam and C.J. Knowles: Biochem. Biophys. Acta, 1984, vol. 786 , pp. $123-32$.

7. P.B. Rodgers: J. Gen. Microbiol., 1978, vol. 108, pp. 261-67.

8. P.B. Rodgers: J. Gen. Microbiol., 1982, vol. 128, pp. 2983-89.

9. M.A. Faramarzia, M. Stagarsa, E. Pensinib, W. Krebsb, and H. Brandl: J. Biotech., 2004, vol. 113 (1-3), pp. 321-26.

10. Y. Kita, H. Nishikawa, and T. Takemoto: J. Biotechnol., 2006, vol. 124, pp. 545-51.

11. H. Hedley and H. Tabachnick: Mineral Dressing Notes, American Cyanamid Co., 1958, no. 23.

12. D.H. Rubisov, V.G. Papangelakis, and P.D. Kondos: Can. Inst. Min. Metall., 1996, vol. 35 (4), pp. 353-61.
13. P. Ling, V.G. Papangelakis, S.A. Argyropoulos, and P.D. Kondos: Can. Metall. Q., 1996, vol. 35 (3), pp. 225-34.

14. L.R.P. de Andrade Lima and D. Hodouin: Hydrometallurgy, 2005, vol. 79, pp. 121-37.

15. K. Haque: CIM Bull., 1992, vol. 85 (963), pp. 31-38.

16. A.R. Heath and J.A. Rumball: Min. Eng., 1998, vol. 11, pp. 999-1010.

17. D.K. Peter and F.G. Wesley: Can. Metall. Q., 1995, vol. 35, pp. $39-45$.

18. M.E. Wadsworth: Int. J. Miner. Process., 1999, vol. 58, pp. 351-68.

19. S. Foucher, F. Battaglia-Brunet, P. d'Hugues, M. Clarens, J.J. Godon, and D. Morin: Hydrometallurgy, 2003, vol. 71 (1-2), pp. 5-12.

20. L. Guzman, M. Segarra, J.M. Chimenos, M.A. Fernandez, and F. Espiell: Hydrometallurgy, 1999, vol. 52, pp. 21-35.

21. G. Cerny: Packag. Technol. Sci., 1992, vol. 5, pp. 77-81.

22. N. Kallay, T. Preocanin, and T. Ivsic: J. Coll. Interface Sci., 2007, vol. 309, pp. 21-27.

23. A.K. Singh, A.K. Jain, and S. Mehtab: Anal. Chem. Acta, 2007, vol. 597 , pp. 322-30. 